\title{
MENINGKATKAN HASIL BELAJAR IPS MELALUI PENERAPAN MODEL PEMBELAJARAN LANGSUNG DI KELAS IV SDN 2 PUUNDOHO
}

\author{
Andi Sri Yuspitalia ${ }^{1)}$, Jamiludin ${ }^{2)}$ \\ ${ }^{1)}$ SDN 2 Puundoho, Kolaka Utara, Indonesia \\ ${ }^{2)}$ Jurusan Pendidikan Sejarah, Universitas Halu Oleo, Kendari, Indonesia \\ email: andisriyuspitalia.pij@gmail.com
}

\begin{abstract}
Abstrak: Tujuan dari penelitian ini adalah untuk meningkatkan hasil belajar Ilmu Pengetahuan Sosial materi Sumber Daya Alam melalui penerapan model pembelajaran langsung pada siswa kelas IV SDN 2 Puundoho. Prosedur penelitian yaitu; (a) perencanaan (planning), (b) pelaksanaan tindakan (action), (c) observasi dan evaluasi (observation and evaluation), dan (d) refleksi (reflection). Jenis data yaitu data kualitatif dan data kuantitatif. Hasil penelitian yaitu pada siklus I kegiatan guru pada tindakan pertama $66,7 \%$ dari rencana pembelajaran yang dapay terlaksana. Sedangkan pada pertemuan kedua siklus I terjadi peningkatan menjadi $80 \%$ rencana pembelajaran yang terlaksana. Kegiatan siswa pada tindakan pertama $66,7 \%$ saja yang dilakukan oleh siswa. Pada pertemuan menjadi $80 \%$. Ketuntasan hasil belajar siswa sebesar 66,7\% atau sebanyak 12 siswa dari 18 siswa telah memperoleh nilai $\geq 70$ dengan nilai rata-rata kelas 70,3. Pada siklus II kegiatan siswa pada tindakan pertama berdasarkan pengamatan observer mencapai $86,7 \%$ sudah terlaksana. Pada pertemuan kedua siklus II $100 \%$ sudah terlaksana secara maksimal. kegiatan guru pada tindakan pertama mencapai 93,3\%. Pada pertemuan kedua siklus II rencana pembelajaran $100 \%$ sudah terlaksana secara maksimal. Ketuntasan belajar siswa meningkat menjadi $94,4 \%$ atau sebanyak sebanyak 17 siswa dari 18 siswa telah memperoleh nilai $\geq 70$ dengan nilai rata-rata kelas 80,6.

Kata kunci: Model pembelajaran, pembelajaran langsung, hasil belajar
\end{abstract}

\section{IMPROVING STUDENT LEARNING OUTCOMES IN IPS LESSON THROUGH THE IMPLEMENTATION OF DIRECT LEARNING MODELS IN CLASS IV SDN 2 PUUNDOHO}

Abstract: The purpose of this study was to improve the learning outcomes of Social Sciences in Natural Resources material through the application of a direct learning model to grade IV students of SDN 2 Puundoho. Research procedures, namely; (a) planning, (b) action, (c) observation and evaluation, and (d) reflection. Types of data are qualitative data and quantitative data. The result of the research is that in cycle I, the teacher's activities in the first action are $66.7 \%$ of the learning plan that can be implemented. Whereas at the second meeting of the first cycle there was an increase to $80 \%$ of the learning plans that were carried out. $66.7 \%$ of students' activities in the first action were carried out by students. At the meeting it became $80 \%$. Completeness of student learning outcomes is $66.7 \%$ or as many as 12 students out of 18 students have obtained a value of 70 with a class average score of 70.3. In cycle II, student activities in the first action based on observer observations reached $86.7 \%$. At the second meeting of the second cycle 100\% has been maximally carried out. teacher activities in the first act reached 93.3\%. At the second meeting of the second cycle the learning plan was 100\% maximized. Student learning completeness increased to $94.4 \%$ or as many as 17 students out of 18 students have obtained a grade of 70 with a class average score of 80.6.

Keywords: Learning model, direct learning, learning outcomes 


\section{Pendahuluan}

Kesempatan belajar siswa dapat ditingkatkan dengan cara melibatkan siswa secara aktif dalam proses belajar-mengajar sehingga dapat meningkatkan minat dan motivasi siswa untuk belajar. Makin banyak siswa terlibat secara aktif dalam proses belajar, makin tinggi pula kemungkinan siswa memperoleh hasil belajar yang baik. Untuk meningkatkan kualitas dalam mengajar hendaknya guru harus mampu merancang metode pembelajaran dan sekaligus mampu melakukannya dalam bentuk interaksi pembelajaran dengan siswa. Sebagian besar yang dilakukan oleh guru tidak lain dari pada menyajikan pengetahuan jadi yang harus diketahui dan dihafalkan oleh siswa. Iklim pembelajaran semacam ini terjadi pula dalam proses pembelajaran IPS. Kondisi pembelajaran IPS di sekolah belum mampu memberikan sesuatu yang bermakna bagi siswa. Fenomena seperti yang dikemukakan tersebut di atas sama dengan proses pembelajaran yang berlangsung pada SDN 2 Puundoho Kabupaten Kolaka Utara.

Dalam praktek pembelajaran yang dilakukan oleh guru, masih banyak didominasi oleh guru. Apa yang dilakukan oleh guru adalah sekedar memindahkan atau mentrasfer pengetahuan dari guru kepada siswa, dengan buku sebagai satu-satunya sumber belajar. Kedaan seperti ini membuat siswa jenuh, pasif, dan tidak menantang siswa untuk berpikir. Kondisi belajar seperti ini berdampak pada hasil belajar siswa. Sehingga menjadikan hasil ulangan harian siswa Kelas IV SDN 2 Puundoho materi sumber daya alam pada semester ganjil tahun pelajaran 2015/2016 masih tergolong rendah. Dari 14 jumlah siswa keseluruhan, terdapat 5 orang siswa atau 35,71\% yang belum mencapai KKM sedangkan 9 orang siswa lainnya atau 64,29\% sudah mencapai KKM yang ditetapkan sekolah sebesar $80 \%$ siswa yang mencapai nilai 70 sesuai Kriteria Ketuntasan Minimal (KKM) yang ditetapkan oleh sekolah. Sebagian siswa masih sulit dalam memahami materi ini, hal ini disebabkan karena metode dan pendekatan yang digunakan guru dalam proses pembelajaran Ilmu Pengetahuan Sosial, penyampaiannya masih lebih banyak didominasi oleh guru menjelaskan mata pelajaran secara teoritis dengan penekanan utama penghafalan pengetahuan atau fakta.

Mengatasi masalah pembelajaran Ilmu Pengetahuan Sosial pada siswa Kelas IV SDN 2 Puundoho dalam proses pembelajaran di kelas, maka salah satu model pembelajaran yang dapat mengaktifkan siswa secara langsung untuk memahami materi yang dipelajari adalah model pembelajaran langsung (direct instruction). Pembelajaran langsung memiliki beberapa keunggulan, salah satunya adalah siswa dapat belajar melalui menirukan pengetahuan, keterampilan dan sikap yang telah dipresentasikan oleh guru secara tahap demi tahap melalui metode ilmiah. Model pembelajaran langsung merupakan salah satu pengajaran yang dirancang khusus untuk menunjang proses belajar siswa yang berkaitan dengan pengetahuan deklaratif dan pengetahuan prosedural yang terstruktur dengan baik yang dapat diajarkan dengan pola kegiatan yang bertahap, serta selangkah demi selangkah Trianto (Hamka, dkk. 2015)

Model pembelajaran Direct Instruction adalah model pembelajaran yang menekankan pada penguasaan konsep atau perubahan perilaku dengan mengutamakan pendekatan deduktif, dengan ciri-ciri sebagai berikut: (1) transformasi dan keterampilan secara langsung, (2) pembelajaran berorientasi pada tujuan tertentu, (3) materi pembelajaran yang telah terstruktur, (4) lingkungan belajar yang telah terstruktur, dan (5) distruktur oleh guru. Guru berperan sebagai penyampai informasi, dan dalam hal ini guru seyogyanya menggunakan berbagai media yang sesuai, misalnya tape recorder, gambar, peragaan, dan sebagainya Sudrajat (Fakhrah, 2015). Menurut Anori (Sukmana, dkk. 2015) kelebihan model pembelajaran langsung (Direct Instruction) adalah: (1) Dapatmenjadi cara untuk menyampaikan informasi yang banyak dalam waktu yang relatif singkat; (2) Dapat digunakan untuk menekankan poin penting atau kesulitan yang mungkin dihadapi siswa; (3) 
Memungkinkan untuk menciptakan lingkungan yang tidak mengancam dan bebas stres bagi siswa; dan (4) Dapat bermanfaat untuk menyampaikan pengetahuan yang tidak tersedia secara langsung bagi siswa.

Penelitian yang dilakukan oleh Mersitas dan Muhsin (2015) bahwa model pembelajraan langsung (Direct Instruction) dapat meningkatkan aktivitas dan hasil belajar siswa. Saran dalam penelitian ini adalah guru perlu memberikan motivasi kepada siswa karena dapat meningkatkan antusiasme siswa dalam kegiatan belajarnya.

Berdasarkan uraian di atas, maka penulis tertarik untuk melakukan suatu penelitian dalam bentuk penelitian tindakan kelas dengan judul: "Meningkatkan Hasil Belajar Siswa pada Mata Pelajaran IPS Melalui Penerapan Model Pembelajaran Langsung di Kelas IV SDN 2 Puundoho Kabupaten Kolaka Utara"

Hasil penelitian yang dilakukan oleh Suryani (2010) dengan judul Penerapan Model Pembelajaran Langsung pada Pembelajaran IPS Materi Sejarah Kerajaan Hindu-Budha dan Islam untuk Meningkatkan Hasil Belajar Siswa Kelas V SD Negeri 1 Langgea Tahun Pelajaran 2009/2010. Pada siklus I rata-rata hasil belajar siswa adalah 71,09 dan ketuntasan belajar siswa mencapai 75,08\%. Pada siklus II rata-rata hasil belajar siswa meningkat menjadi 76,86 dan ketuntasan belajar siswa meningkat menjadi 89,57\%. Kesimpulan dari penelitian ini adalah pembelajaran IPS dengan menggunakan model pembelajaran langsung lebih efektif mengingkatkan hasil belajara siswa kelas V SD Negeri 1 Langgea.

Hasil penelitian yang dilakukan oleh Zarman (2011) dengan judul Meningkatakan Hasil Belajar IPS Siswa Kelas IV Negeri 16 Baruga Melalui Penerapan Model Pembelajaran Langsung. Pada siklus I rata-rata hasil belajar siswa adalah 73,04 dan ketuntasan belajar siswa mencapai 73,52\%. Pada siklus II rata-rata hasil belajar siswa meningkat menjadi 76,06 dan ketuntasan belajar siswa meningkat menjadi 95,12\%. Berdasarkan hasil tersebut disimpulkan bahwa model pembelajaran langsung efektif terhadap peningkatan hasil belajar siswa.

Model pembelajaran langsung dirancang secara matang dan dilaksanakan secara tepat diharapkan dapat mendorong siswa lebih dapat meningkatkan persiapan dalam menerima pelajaran. Peningkatan motivasi belajar siswa juga diharapkan membawa dampak positif yaitu peningkatan hasil belajar siswa.

Masalah dalam penelitian adalah apakah penerapan model pembelajaran langsung dapat meningkatkan hasil belajar siswa pada materi Sumber Daya Alam di kelas IV SDN 2 Puundoho Kabupaten Kolaka Utara?. Tujuan penelitian adalah untuk meningkatkan hasil belajar Ilmu Pengetahuan Sosial materi Sumber Daya Alam melalui penerapan model pembelajaran langsung pada siswa kelas IV SDN 2 Puundoho. Penelitian ini diharapkan dapat memberikan manfaat bagi guru, siswa, sekolah dan penelitian lainnya.

\section{Metode}

Penelitian ini termasuk jenis Penelitian Tindakan Kelas, karena penelitian ini dilakukan di dalam kelas dan fokus penelitian ini adalah kegiatan pembelajaran berupa perilaku guru dan siswa dalam berinteraksi dengan tujuan untuk memperbaiki pembelajaran. Penelitian ini dilaksanakan pada semester ganjil tahun pelajaran 2016/2017 di kelas IV SDN 2 Puundoho Kabupaten Kolaka Utara. Subjek dalam penelitian ini adalah siswa kelas IV SDN 2 Puundoho dengan jumlah siswa 18 orang yang terdiri dari laki-laki 8 orang dan perempuan 10 orang yang terdaftar pada semester ganjil tahun pelajaran 2016/2017. Faktor yang diteliti dalam penelitian ini adalah 1) faktor siswa, 2) Faktor guru dan faktor 3) hasil belajar. Penelitian Tindakan Kelas ini dilaksanakan dalam 2 (dua) siklus. Adapun prosedur penelitian tindakan ini meliputi: (1) Perencanaan, (2) Pelaksanaan Tindakan, (3) Observasi dan Evaluasi, dan (4) Refleksi dalam setiap siklus. Data dalam penelitian ini yaitu data kualitatif dan data 
kuantitatif. Data kualitatif diperoleh melalui lembar observasi sedangkan data kuantitatif melalui tes hasil belajar siswa.

Analisis data dimulai dari analisis terhadap data yang telah diperoleh berdasarkan hasil observasi dan tes kemampuan siswa menyelesaikan soal tentang materi sumber daya alam. Data terdiri atas aspek aktivitas guru, aspek aktivitas siswa, dan aspek hasil kemampuan menyelesaikan soal-soal evaluasi materi sumber daya alam di kelas IV SDN 2 Puundoho melalui penggunaan model pembelajaran langsung. Analisis tersebut menggunakan rumus sebagai berikut,

a. Seorang siswa dikatakan tuntas belajar secara individual jika siswa tersebut telah memperoleh nilai minimal 70.

$$
\text { Nilai akhir }=\frac{\text { Skor perolehan siswa }}{\text { Skor total }} \times 100
$$

b. Untuk mengetahui persentase ketuntasan belajar secara klasikal, digunakan rumus:

Jumlah siswa yang tuntas

Jumlah seluruh siswa

Indikator kinerja dalam penelitian tindakan kelas ini adalah minimal $80 \%$ skenario pembelajaran telah tercapai dan siswa dikatakan tuntas jika minimal $80 \%$ siswa telah memperoleh nilai $\geq 70$.

\section{Hasil}

1. Hasil Belajar Siswa

Pada siklus I siswa yang tuntas mencapai 12 orang atau sebesar $66,67 \%$ dengan ratarata nilai 70,3 . Pada siklus II jumlah siswa yang tuntas mencapai 17 orang atau sebesar $94,4 \%$ dengan nilai rata-rata 80,6 .

2. Aktivitas Mengajar Guru

Aktivitas mengajar guru mengalami peningkatan dengan persentase siklus I sebesar $66,7 \%$ pada pertemuan pertama dan $80 \%$ pada pertemuan kedua, sedangkan pada siklus II sebesar $93,3 \%$ pada pertemuan pertama dan pertemuan kedua sebesar $100 \%$.

3. Aktivitas Belajar Siswa

Aktivitas belajar siswa juga mengalami peningkatan dengan persentase siklus I sebesar $66,7 \%$ pada pertemuan pertama dan $80 \%$ pada pertemuan kedua, sedangkan pada siklus II sebesar $86,7 \%$ pada pertemuan pertama dan pertemuan kedua sebesar $100 \%$.

\section{Pembahasan}

1. Hasil Belajar Siswa

Berdasarkan kekurangan-kekurangan yang masih ada pada Siklus I, berdampak pada pencapaian hasil berlajar Ilmu Pengetahuan Sosial siswa pada tindakan siklus I yang hanya mencapai 66,7\% atau 10 siswa dari 18 siswa yang telah memperoleh nilai $\geq 70$, dengan nilai rata-rata 70,3. Hal ini menunjukkan bahwa tindakan siklus I belum mencapai indikator keberhasilan yang ditetapkan dalam penelitian ini yaitu minimal $80 \%$ siswa memperoleh nilai $\geq 70$, maka penelitian dilanjutkan pada tindakan siklus II.

Pada siklus II, model pembelajaran langsung kembali dilaksanakan, siswa dibentuk dalam kelompok dengan teman sebangkunya. Ketuntasan belajar siswa pada Siklus II secara klasikal mencapai 94,4\% atau 17 siswa memperoleh nilai $\geq 70$, dengan nilai rata-rata 80,6. Hal ini menunjukkan bahwa indikator keberhasilan telah tercapai dalam hal ini telah terlaksananya skenario pembelajaran dan siswa yang memperoleh nilai $\geq 70$ melebihi $80 \%$.

Hasil evaluasi yang dilakukan pada siklus II dapat dikatakan bahwa penetapan model pembelajaran langsung memberikan dampak yang positif terhadap hasil belajar siswa. Mereka 
sudah mampu bersosialisasi dengan baik, serta dapat memahami materi Sumber Daya Alam yang sesungguhnya, bahkan sebagian besar siswa sudah berani mengeluarkan pendapat dan menjawab pertanyaan yang diberikan. Ada beberapa siswa yang hingga akhir tindakan siklus memiliki hasil belajar <70. Meskipun demikian, mereka memberikan penghargaan dan sikap positif pada saat model pembelajaran langsung diterapkan.

Berdasarkan hasil observasi pada siklus II, guru dan siswa telah melakukan kegiatan pembelajaran sesuai yang diharapkan. Kekurangan-kekurangan pada siklus I sudah dapat diperbaiki. Guru sudah mampu mengorganisasikan waktu dengan baik sehingga tidak ada lagi kegiatan yang tidak dilaksanakan. Guru/peneliti sudah mampu mengefektifkan siswa dalam mempelajari Sumber Daya Alam dan pemantauan dan bimbingan terhadap siswa yang mengalami kesulitan dalam pembelajaran sudah baik.

Pada tindakan siklus II, semua skenario pembelajaran telah tercapai dengan ketuntasan hasil belajar siswa secara klasikal mencapai 94,4\% atau 17 dari 18 siswa telah memperoleh nilai $\geq 70$, dengan nilai rata-rata 80,6 . Karena indikator keberhasilan telah tercapai dalam hal ini telah terlaksananya skenario pembelajaran dengan baik dan siswa yang memperoleh nilai $\geq 70$ melebihi $80 \%$, maka penelitian ini dihentikan pada tindakan siklus II.

\section{Aktivitas Mengajar Guru}

Berdasarkan hasil observasi pada siklus I Aktivitas guru/peneliti dalam melaksanakan pembelajaran meningkat sebelum diterapkan model pembelajaran langsung namun demikian masih terdapat kekurangan-kekurangan yang perlu diperbaiki antara lain pada pelaksanaan tindakan pertama, peneliti belum melaksanakan semua proses pembelajaran seperti pemantauan terhadap kegiatan siswa pada saat mempelajari Sumber Daya Alam belum optimal, memberikan kesimpulan atau jawaban akhir dari semua pertanyaan belum terlaksana, kegiatan membimbing siswa untuk membuat rangkuman belum terlaksana dan pelaksanaan pembelajaran belum sesuai dengan waktu yang ditentukan serta pemantauan terhadap kegiatan siswa dalam kelompok masih ada yang terabaikan serta pelaksanaan pembelajaran belum sesuai dengan waktu yang ditentukan dan pada pelaksanaan tindakan kedua, peneliti sudah dapat melaksanakan semua proses pembelajaran sesuai waktu yang ditentukan dan pemantauan terhadap kegiatan siswa pada saat mempelajari Sumber Daya Alam sudah mulai optimal terbukti dengan tidak ada kelompok yang terabaikan dalam pemantauan peneliti serta pelaksanaan pembelajaran sudah sesuai dengan waktu yang ditentukan. Dari hasil analisis observer bersama peneliti menunjukkan bahwa aktivitas guru pada siklus I $80 \%$ aspek yang diamati telah terlaksana namun belum maksimal dan pada siklus II semua aspek telah dilaksanakan secara maksimal dengan persentase keberhasilan mencapai $100 \%$.

\section{Aktivitas Belajar Siswa}

Aktivitas siswa pada pelaksanaan tindakan pertama, siswa terlihat masih asing dengan model pembelajaran langsung yang diterapkan hal ini tergambar dari sikap siswa yang masih pasif selama berada dalam kelompok dalam mempelajari Sumber Daya Alam, siswa belum termotivasi dalam mengikuti pembelajaran dengan pembelajaran langsung dan siswa belum bisa mengemukakan pendapatnya dan tidak memberikan sanggahan pada saat temannya yang berbeda mempresentasikan hasil kerjanya, serta siswa masih takut jika namanya ditunjuk dan pada pelaksanaan tindakan kedua, siswa terlihat sudah tidak merasa asing lagi dengan model pembelajaran langsung yang diterapkan. Hal ini tergambar dari sikap siswa yang sudah mulai aktif selama berada dalam kelompoknya dan bekerjasama dalam mempelajari Sumber Daya Alam, siswa mengerjakan tugas, siswa sudah mulai berani mengemukakan pendapatnya, sehingga prestasi belajar siswa meningkat. 
Pada Siklus II, aktivitas siswa mengalami peningkatan karena siswa sudah terlihat aktif dalam mengikuti kegiatan pembelajaran serta siswa sudah berani menyampaikan pendapat/gagasannya. Dari hasil analisis aktivitas siswa yang dilakukan oleh observer bersama peneliti menunjukan bahwa pada siklus I aktivitas siswa mencapai $80 \%$ namun belum maksimal dan pada siklus II sudah mencapai $100 \%$ atau semua aspek telah terlaksana dengan maksimal.

\section{Simpulan}

Berdasarkan hasil penelitian yang dipaparkan berupa data kualitatif dan data kuantitatif dalam penelitian ini, menunjukkan bahwa penerapan model pembelajaran langsung dapat meningkatkan hasil belajar IPS siswa kelas IV SD Negeri 2 Puundoho. Hal ini terlihat dari:

1. Persentase ketuntasan hasil belajar siswa tindakan siklus I diperoleh bahwa ketuntasan hasil belajar siswa secara klasikal terhadap materi pelajaran sebesar 66,7\% dengan nilai rata-rata 70,3 kemudian mengalami peningkatan pada hasil tes tindakan siklus II dengan pencapaian hasil belajar siswa secara klasikal terhadap materi sebesar 94,4\% dengan nilai rata-rata 80,6 .

2. Aktivitas mengajar guru mengalami peningkatan dengan persentase siklus I sebesar $66,7 \%$ pada pertemuan pertama dan $80 \%$ pada pertemuan kedua, sedangkan pada siklus II sebesar 93,3\% pada pertemuan pertama dan kedua sebesar $100 \%$. Hal ini telah mencapai indikator kinerja yang ditentukan dalam penelitian ini yakni sebesar $80 \%$.

3. Aktivitas belajar siswa mengalami peningkatan dengan persentase siklus I sebesar $66,7 \%$ pada pertemuan pertama dan $80 \%$ pada pertemuan kedua, sedangkan pada siklus II sebesar $86,7 \%$ pada pertemuan pertama dan kedua sebesar $100 \%$. Hal ini telah mencapai indikator kinerja yang ditentukan dalam penelitian ini yakni sebesar $80 \%$.

\section{Referensi}

Fakhrah. 2015. Penerapan Model Pembelajran Langsung (Direct Instraction) untuk Meningkatkan Keterampilan Proses Sains pada Materi Pengaplikasian Filium Arthropoda. Jurnal Edukasi dan Sains Biologi JESBIO Vol. IV No. 2. https://www.neliti.com/id/publications/77338/penerapan-model-pembelajaranlangsung-direct-instruction-untuk-meningkatkan-kete.

Hamka, L. dkk. 2015. Keefektifan Penerapan Model Pembelajaran Langsung Materi Sistem Gerak di SMA Negeri 1 Donri-donri. Jurnal Bionature Vol. 16. No. 1 https://ojs.unm.ac.id/bionature/article/download/1571/637

Mersita, N. \& Muhsin. 2015. Penerapan Model Pembelajaran Alngsung (Direct Instruction) Untuk Meningkatkan Aktivitas dan Hasil Belajar pada Mata Pelajaran Kearsipan Siswa Kelas XI AP SMK YPE Nusantara Slawi. Economic Education Analysis Journal Vol. 4 Np. 3https://journal.unnes.ac.id/sju/index.php/eeaj/article/view/8479

Sukmana, E. dkk. 2015. Pengaruh Model Pembelajaran Langsung (Direct Instruction) Disertai Media gambar Terhadap Hasil Belajar Biologi Siswa Kelas VII SMP Negeri 1 Tambusai Utara. https://media.neliti.com/media/publications/110804-ID-none.pdf. 
Suryani. 2010. Keefektifan Model Pembelajaran Langsung pada Pembelajaran IPS Materi Sejarah Kerajaan Hindu-Budha dan Islam pada Siswa Kelas V SDN 1 Langgea.

Zarman, 2011. Keefektifan Model Pembelajaran Langsung Terhadap Hasil Belajar Siswa Materi Kenampakan Alam dan Sosial Negara-negara ASEAN pada Siswa Kelas IV SDN 16 Baruga Tahun Ajaran 2010/2011. Kendari: FKIP. Unhalu. 